\title{
Incorporation of conjugated linoleic acid (CLA) and $\alpha$-linolenic acid (LNA) in pacu fillets
}

Deoclécio José BARILLI ${ }^{1 *}$, Mayara SANTAROSA², Ana Beatriz ZANQUI², Wilson Rogério BOSCOLO ${ }^{1}$, Aldi FEIDEN ${ }^{1}$, Wilson Massamitu FURUYA³ , Sandra Terezinha Marques GOMES², Jesuí Vergílio VISENTAINER², Nilson Evelázio de SOUZA², Makoto MATSUSHITA²

\begin{abstract}
The objective of this study was to evaluate the incorporation of conjugated linoleic acid and $\alpha$-linolenic acid in fillets of pacu fish raised in net cages and fed diets enriched with these acids. The fish were fed for 49 days, and at the end of this period the fatty acid content in the fillets was determined by gas chromatography. Concentrations of $\alpha$-linolenic acid, eicosapentaenoic acid, and the total omega-3 (n-3) fatty acid in the fillets increased, improving the n-6/n-3 ratio. In addition, the incorporation of conjugated linoleic acid in the fish fillets proved well established. This study showed that the use of diets enriched with conjugated linoleic acid and $\alpha$-linolenic acid results in the incorporation of these acids in the of pacu fish fillets, improving their nutritional quality.
\end{abstract}

Keywords: Piaractus mesopotamicus; fatty acids; net cages.

\section{Introduction}

The changes in the eating habits caused by industrialization has led to an increase in the consumption of foods with a high content of omega- 6 fatty acids (n-6) and a decrease in the consumption of foods rich in omega-3 fatty acids (n-3). This imbalance in the $n-6 / n-3$ ratio was around $1: 1$ to $2: 1$ during the pre-industrialization period, especially due to the consumption of seafood, and it reached values ranging from 10:1 to $20: 1$ (Simopoulos, 2002). In addition, the balance between the polyunsaturated fatty acids is associated with prevention of coronary heart and cardiovascular disease, rheumatoid arthritis, depression, cancers, diabetes, and anti-inflammatory action (Navarro et al., 2012; Sanderson et al., 2002).

The polyunsaturated fatty acids of the $\mathrm{n}-3$ series, e.g. eicosapentaenoic (EPA, 20:5n-3) and docosahexaenoic (DHA, 22:6n-3), have the essential $\alpha$-linolenic acid (LNA; 18:3n-3) as their precursor. The fatty acids EPA and DHA are associated with the reduction of risk factors for cardiovascular diseases (Haglund et al., 1998), psoriasis (Mayser et al., 1998) and cancer (Kimura et al., 2001).

Conjugated linoleic acid (CLA) is a term utilized to describe positional and geometric isomers of the linoleic acid (LA 18:2n6); the two main occurring isomers are $9 c, 11 t$ and $10 t, 12 c$. These compounds occur in meat and dairy products from ruminants, but they are also present at lower levels in many other foodstuffs (Chin et al., 1992; Pariza et al., 2001).

Among the health benefits attributed to the CLA, anticarcinogenesis (Ha et al., 1987; Ip et al., 1996), reduction in the development of arteriosclerosis (Chouinard et al., 1999;
Kritchevsky et al., 2004), immunomodulation (Cook \& Pariza, 1998), and the capacity to change lipid metabolism in humans (Gaullier et al., 2004) stand out.

The amount of CLA found in foods is small, and their ingestion by humans varies between 0.5-1.0 g/day/person (Chin et al., 1992). Thus, supplementing CLA by consuming foods such as fish is an alternative to increase intake of this acid.

Studies show that dietary fatty acids are transferred to the fish fillets via their diet (Henderson, 1996). Accordingly, the incorporation of linseed oil in fish diet has improved their profile of n-3 fatty acids (Justi et al., 2003; Visentainer et al., 2005).

Similarly, some other studies have demonstrated the possibility of incorporating CLA in fish fillets by feeding them diets based on this acid (Leaver et al., 2006; Santos et al., 2007a, b).

$\mathrm{Pacu}$, a species originated in the rivers that make up the Prata Basin, is farmed mainly in the South and Southeast regions of Brazil. It has a great potential for commercialization and for farming in intensive-culture systems, rusticity, optimal growth rates, and adaptation to artificial feeding (Castagnolli \& Cyrino, 1986) in addition to having a very much appreciated meat, of high commercial value. However, like the other tropical-climate fish species, pacu is poor in fatty acids of the $n-3$ series.

The objective of this study was to evaluate the incorporation of conjugated linoleic acid (CLA) and $\alpha$-linolenic acid (LNA) in fillets of pacu reared in net cages and fed diets enriched with these acids.

\footnotetext{
Received 31 July, 2013

Accepted 2 Nov., 2013 (006165)

${ }^{1}$ Centro de Engenharias e Ciências Exatas, Universidade Estadual do Oeste do Paraná - Unioeste, Toledo, PR, Brasil, e-mail: tatobarilli@hotmail.com

2 Departamento de Química, Universidade Estadual de Maringá - UEM, Maringá, PR, Brasil

${ }_{3}$ Departamento de Zootecnia, Universidade Estadual de Ponta Grossa - UEPG, Ponta Grossa, PR, Brasil

${ }^{*}$ Corresponding author
} 


\section{Materials and methods}

\subsection{Fish, diet, and management}

The experiment was conducted in net cages in the Center for Development of Fish Farming Technologies, located in the tank of the Itaipu Binacional Dam, in the municipality of Santa Helena/PR, Brazil, at coordinates W 54 $21^{\circ}$ and S $24^{\circ} 51^{\prime}$.

The fish ( $\mathrm{n}=300 ; 220 \pm 11.45 \mathrm{~g}$ initial weight $)$ were divided into 12 net cages in groups of 25 individuals and were subjected to four treatments with six replications each.

All fish were initially acclimated for a period of 30 hours, receiving only Diet A (control). Afterwards, some fish continued to be fed $\operatorname{diet} \mathrm{A}$, and the others received diets $\mathrm{B}$ (1\% LNA), C ( $1 \%$ CLA $)$, and D ( $0.5 \%$ LNA + 0.5\% CLA), which were formulated according to Table 1 . The fish were fed an extruded commercial diet (8 mm; Supra ${ }^{\oplus}$, Paraná, Brazil) containing $32 \%$ crude protein and $3.062 \mathrm{kcal} \mathrm{kg}^{-1}$ digestible energy; and each oil was manually poured into the feed and allowed to drain out.

The fish were fed amounts corresponding to $2 \%$ of the adjusted body weight three times a day (08:00, 13:00 and 17:00 h). Six fish were collected from each net cage at the beginning (time zero) and end of the experiment to evaluate fatty acid incorporation and every seven days (for 49 days) to determine the incorporation profiles of CLA. After each collection, the fish were weighed and the fillets were ground, homogenized, and wrapped in polyethylene bags under nitrogen gas until analyses.

\subsection{Chemical composition and specific growth rate}

Moisture and ash were determined gravimetrically by oven drying at $105^{\circ} \mathrm{C}$ and incineration in a muffle furnace at $600^{\circ} \mathrm{C}$, respectively, according to Cunnif (1998). The crude protein content was obtained by the method of Kjeldahl (Cunnif, 1998) using the 6.25 nitrogen-to-protein conversion factor.

The specific growth rate (SGR) was calculated according to Izquierdo et al. (2005) using Equation 1:
$S G R=\frac{\ln (\text { final body weight })-\ln (\text { initial body weight })}{t} \times 100$

were: $t=$ experimental period (days).

\subsection{Total lipid extraction and analysis of fatty acid methyl esters}

The total lipids (TL) were extracted by the method of Bligh \& Dyer (1959), and the fatty acid methyl esters (FAME) were prepared by methylation of the triacylglycerols, as described by Hartman \& Lago (1973).

The FAME were separated using a gas chromatograph (Shimadzu 14A, Japan), equipped with a flame ionization detector (FID) and a fused-silica capillary column (Varian, USA) (CP - 7420 Select FAME; $100 \mathrm{~m}$ length, 0.25 internal diameter and $0.25 \mu \mathrm{m}$ cyanopropyl film). The temperature of the column was set at $165^{\circ} \mathrm{C}$ for $18 \mathrm{~min}$, and it was then increased to $180^{\circ} \mathrm{C}$ $\left(30^{\circ} \mathrm{C} / \mathrm{min}\right)$ for $22 \mathrm{~min}$, and finally to $240^{\circ} \mathrm{C}\left(15^{\circ} \mathrm{C} / \mathrm{min}\right)$ for $20 \mathrm{~min}$. The temperature of the injector and detector was $260^{\circ} \mathrm{C}$. The gas flows (White Martins) were $1.2 \mathrm{~mL} / \mathrm{min}$ for the carrier gas $\left(\mathrm{H}_{2}\right) ; 30 \mathrm{~mL} / \mathrm{min}$ for the auxiliary gas $\left(\mathrm{N}_{2}\right)$; and $30 \mathrm{~mL} / \mathrm{min}$ and $300 \mathrm{~mL} / \mathrm{min}$ for $\mathrm{H}_{2}$ and the synthetic air flame, respectively. A two microliters injection was performed, and the sample split ratio was $1 / 50$.

The peak areas were determined using Clarity Lite software version 2.4.1.91. The fatty acids were identified by comparing the retention times of the FAME peaks with the corresponding peaks in the standards (Sigma Co., St. Louis, MO, USA). The fatty acids (FA) $\left(\mathrm{mg} \mathrm{g}^{-1} \mathrm{TL}\right)$ were quantified in relation to the internal standard, methyl tricosanoate (Sigma ${ }^{\circledast}$ ), according to Joseph \& Ackman (1992) using the following Equation 2:

$$
F A(m g / g T L)=\frac{A_{x} \times W_{I S} \times C F_{x}}{A_{I S} \times W_{x} \times C F_{A E}}
$$

where: $A_{x}$ is the area of a specific fatty acid; $W_{S I}$ is the weight of the internal standard (mg); $\mathrm{CF}_{\mathrm{x}}$ is the theoretical correction factor; $A_{I S}$ is the area of the internal standard (PI), $W_{x}$ is the

Table 1. Composition (\%) of the experimental diets ${ }^{\mathrm{a}}$.

\begin{tabular}{|c|c|c|c|c|}
\hline \multirow[t]{2}{*}{ Ingredients } & \multicolumn{4}{|c|}{ Diets } \\
\hline & A & $\mathrm{B}$ & $\mathrm{C}$ & $\mathrm{D}$ \\
\hline Soybean oil & 4.00 & 2.15 & 2.33 & 3.12 \\
\hline Flaxseed oil ${ }^{\mathrm{b}}$ & 0.00 & 1.85 & 0.00 & 0.46 \\
\hline Supplement LUTA-CLA ${ }^{\oplus} 60$ BASFc $^{c}$ & 0.00 & 0.00 & 1.67 & 0.42 \\
\hline \multicolumn{5}{|l|}{ Proximate composition $^{\mathrm{d}}$} \\
\hline Moisture & $7.50 \pm 0.01$ & $7.36 \pm 0.04$ & $7.64 \pm 0.02$ & $7.47 \pm 0.02$ \\
\hline Crude Protein & $32.30 \pm 0.38$ & $32.97 \pm 0.31$ & $31.92 \pm 0.34$ & $32.20 \pm 0.33$ \\
\hline Total Lipids & $8.60 \pm 0.30$ & $8.25 \pm 0.23$ & $8.55 \pm 0.29$ & $8.62 \pm 0.28$ \\
\hline Ash & $10.47 \pm 0.01$ & $10.60 \pm 0.04$ & $10.56 \pm 0.02$ & $10.58 \pm 0.04$ \\
\hline$\alpha$-Linolenic Acid & 0.00 & 1.00 & 0.00 & 0.50 \\
\hline Conjugated Linoleic Acid & 0.00 & 0.00 & 1.00 & 0.50 \\
\hline
\end{tabular}


weight of the sample $(\mathrm{g})$; and $\mathrm{CF}_{\mathrm{AE}}$ is the conversion factor of methyl ester to fatty acid.

The experimental correction factor $\left(\mathrm{CF}_{\mathrm{AE}}\right)$ of the flame ionization detector was determined according to Visentainer \& Franco (2006) using a standard mixture solution of fatty acid methyl esters (189-19 Sigma) at known concentrations, including the internal standard methyl tricosanoate (23:0). The factors were calculated using Equation 3 and the average of 4 repetitions, as shown in Table 2 .

$C F_{A E}=\frac{A_{I S} \times W_{x}}{A_{x} \times W_{I S}}$

where: $\mathrm{A}_{\mathrm{IS}}=$ area of the internal standard; $\mathrm{W}_{\mathrm{SI}}=$ weight of the internal standard; $A_{x=}$ area of the specific fatty acid, and $\mathrm{W}_{\mathrm{x}}=$ weight of the specific fatty acid.

The limit of detection (LOD) and limit of quantification (LOQ) were estimated by triplicate analysis of successively diluted methyl arachidate standard solution $\left(1.0 \mathrm{mg} \cdot \mathrm{mL}^{-1}\right)$ considering the signal-to-noise ratio relative to the background signal as 3 and 10, respectively (Analytical Methods Committee, 1987).

Table 2. Experimental and theoretical response factors for the internal standard methyl tricosanoate (23:0).

\begin{tabular}{|c|c|c|}
\hline FAME & $\begin{array}{l}\text { Theoretical correction } \\
\text { factor }\left(\mathrm{F}_{\mathrm{CT}}\right)\end{array}$ & $\begin{array}{c}\text { Experimental correction } \\
\text { factor }\left(\mathrm{CF}_{\mathrm{AE}}\right)^{\mathrm{a}}\end{array}$ \\
\hline $14: 0$ & 1.0803 & $1.0614 \pm 0.0099$ \\
\hline $14: \ln -7$ & 1.0713 & $1.0619 \pm 0.0106$ \\
\hline $15: 0$ & 1.0665 & $1.0579 \pm 0.0109$ \\
\hline $15: 1 n-9$ & 1.0581 & $1.0583 \pm 0.0105$ \\
\hline $16: 0$ & 1.0546 & $1.0547 \pm 0.0096$ \\
\hline $16: 1 n-9$ & 1.0468 & $1.0551 \pm 0.0098$ \\
\hline $16: 1 n-7$ & 1.0468 & $1.0551 \pm 0.0095$ \\
\hline $16: 1 n-5$ & 1.0468 & $1.0551 \pm 0.0098$ \\
\hline $17: 0$ & 1.0441 & $1.0519 \pm 0.0105$ \\
\hline $17: 1 n-9$ & 1.0366 & $1.0522 \pm 0.0096$ \\
\hline 18:0 & 1.0347 & $1.0493 \pm 0.0097$ \\
\hline $18: 1(11 t)$ & 1.0276 & $1.0496 \pm 0.0099$ \\
\hline $18: 1 n-9$ & 1.0276 & $1.0496 \pm 0.0100$ \\
\hline $18: 1 n-7$ & 1.0276 & $1.0496 \pm 0.0102$ \\
\hline $18: 2 n-6$ & 1.0207 & $1.0500 \pm 0.0098$ \\
\hline $18: 3 n-6$ & 1.0137 & $1.0504 \pm 0.0099$ \\
\hline $18: 3 n-3$ & 1.0137 & $1.0504 \pm 0.0104$ \\
\hline $20: 1 n-9$ & 1.0124 & $1.0452 \pm 0.0100$ \\
\hline $18: 2(9 c, 11 t)$ & 1.0207 & $1.0500 \pm 0.0105$ \\
\hline $18: 2(10 t, 12 c)$ & 1.0207 & $1.0500 \pm 0.0104$ \\
\hline $20: 2 n-6$ & 1.0061 & $1.0455 \pm 0.0111$ \\
\hline $20: 3 n-6$ & 0.9998 & $1.0458 \pm 0.0101$ \\
\hline $22: 0$ & 1.0057 & $1.0412 \pm 0.0099$ \\
\hline $22: 1 n-9$ & 0.9999 & $1.0414 \pm 0.0097$ \\
\hline $20: 3 n-3$ & 0.9998 & $1.0458 \pm 0.0099$ \\
\hline $20: 4 n-6$ & 0.9936 & $1.0461 \pm 0.0098$ \\
\hline $20: 5 n-3$ & 0.9878 & $1.0464 \pm 0.0097$ \\
\hline $22: 4 n-6$ & 0.9828 & $1.0422 \pm 0.0093$ \\
\hline $22: 5 n-3$ & 0.9770 & $1.0464 \pm 0.0104$ \\
\hline $22: 6 n-3$ & 0.9713 & $1.0427 \pm 0.0099$ \\
\hline
\end{tabular}

${ }^{a}$ Means \pm standard deviation $(\mathrm{n}=4)$.

\subsection{Statistical analysis}

The results were subjected to variance analysis (ANOVA) at the $5 \%$ of significance level, using the software Statistica 7 (Stat Soft Inc., Tulsa, OK, USA), and the means were compared by the Tukey test.

\section{Results and discussion}

The fatty acids of the $n-3$ series are considered essential for freshwater fish, and therefore, they must be acquired through their diet. However, these fish have enzymes able to convert ALA into EPA and DHA fatty acids. Table 3 shows the fatty acid profile of the experimental diets. The presence of CLA isomers in the diets $C$ and $D$, resulting from the addition of the supplement and flaxseed oil in diets B and D, can be seen when compared to the control diet.

The variation in the chemical composition of the fish may result from some endogenous and exogenous factors, among which are: feeding, environmental factors, and temperature and season of the year (Moreira et al., 2001). The composition (\%) of the fillets of pacu fed the experimental diets A, B, C, and D are given in Table 4 . The main changes in the initial composition of the fillets were: increase $(\mathrm{P}<0.05)$ in the total lipid concentration for the fish fed diet $\mathrm{B}$ and consequent reduction in the water content and increase in the crude protein level in the fillets of fish fed diets $\mathrm{C}$ and $\mathrm{D}$.

Fountoulaki et al. (2009) and Kennedy et al. (2007) evaluated the fatty acid profiles of gilt-head bream (Sparus aurata L.) and Atlantic cod (Gadus morhua L.) fed commercial diets enriched with vegetable oils, fish oil, and CLA, respectively. Unlike the results obtained in the present study, the authors found no changes in the composition (\%) of these fish fillets.

Table 5 shows the weight evolution of and the SGR of the fish in the four treatments. At the end of the experiment (49 days), there were no significant differences $(\mathrm{P}>0.05)$ in weight gain or specific growth rate between the fish fed different diets. These results demonstrate that the addition of linseed oil and CLA to the diet did not affect fish growth. However, the experimental diets used in this study provided better SGR than those used by Izquierdo et al. (2005) and Fountoulaki et al. (2009), varying between $0.62-0.68$ and $0.75-0.90$, for fish fed different vegetable oils.

Table 6 presents the fatty acid profile, in $\mathrm{mg} \mathrm{g}^{-1}$ of total lipids (TL), the sums of saturated (SFA), monounsaturated (MUFA), and polyunsaturated (PUFA) fatty acids, omega-6 (n-6) and omega-3 (n-3) series, PUFA/SFA, and n-6/n-3 ratios of pacu fillets fed experimental diets for 49 days.

The main fatty acids found in the fish fillets subjected to the four treatments were oleic acid (18:1 n-9), palmitic acid (16:0), linoleic acid (18:2 n-6), and stearic acid (18:0) accounting for more than $75 \%$ of the amount of fatty acids in the fillets. These results are close to those found by Moreira et al. (2001), who studied three species of non-native fish of the genus Brycon (reared in cages) and Brycon (native) captured in the rivers of the Prata Basin. 
Table 3. Fatty acid profile ( $\mathrm{mg} \mathrm{g}^{-1}$ of total lipids) of the experimental diets.

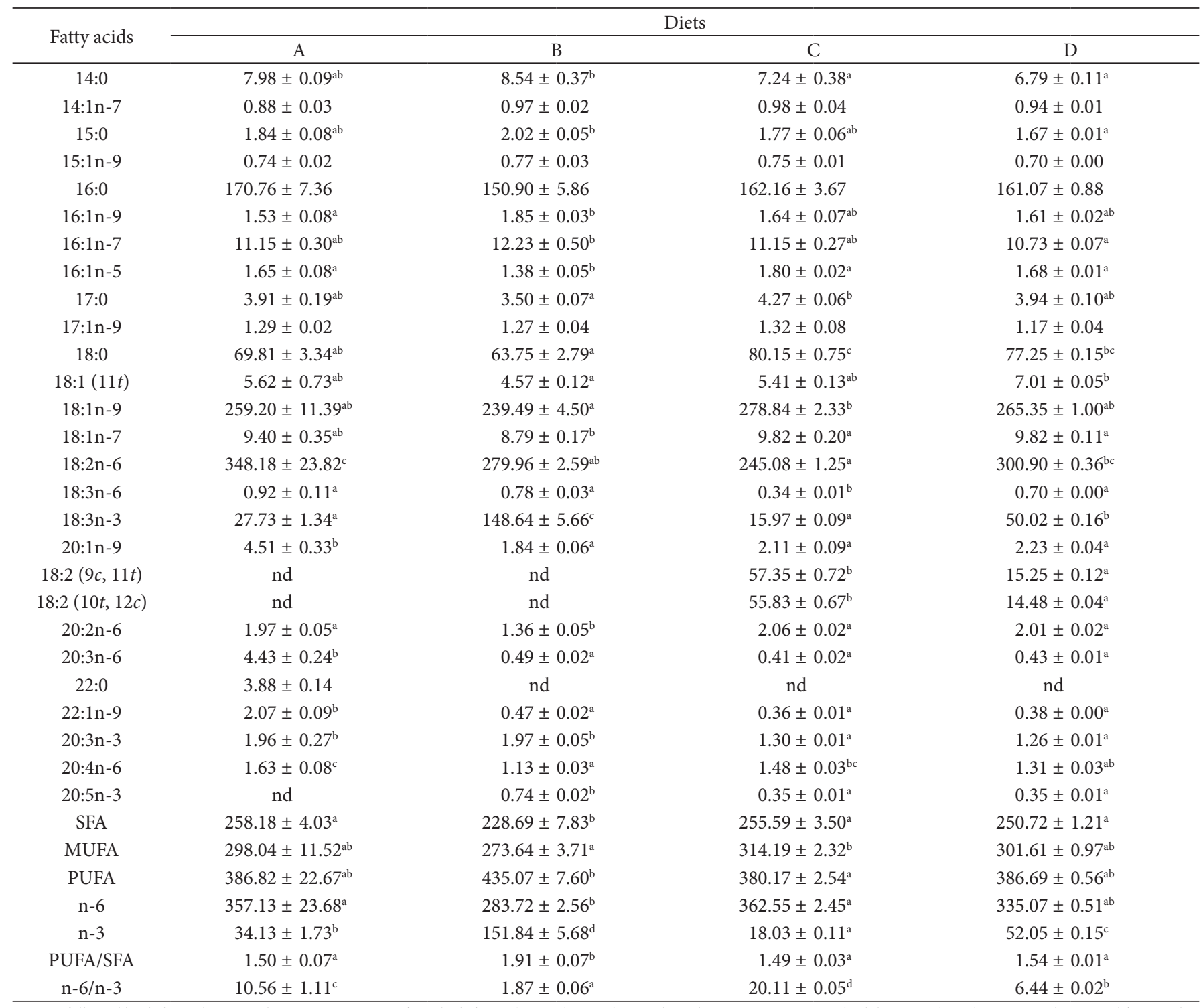

Means followed by different letters in the same row are significantly different $(\mathrm{P}<0.05)$ according to the Tukey test; Means \pm standard deviation $(\mathrm{n}=6)$; SFA $=$ total saturated fatty acids; MUFA = total monounsaturated fatty acids; PUFA = total polyunsaturated fatty acids; $\mathrm{n}-6=$ total $\mathrm{n}-6$ fatty acids; $\mathrm{n}-3=$ total $\mathrm{n}-3$ fatty acids; nd $=$ not detected $\left(\right.$ detection limit $=0.015 \mathrm{mg} \mathrm{g}^{-1}$ ).

Table 4. Composition (\%) of the fillets of fish fed the experimental diets.

\begin{tabular}{ccrrrr}
\hline \multirow{2}{*}{ Analysis } & Initial & \multicolumn{3}{c}{ Diets } \\
\cline { 2 - 6 } & & A & B & C & D \\
\hline Moisture & $72.31 \pm 0.12^{\mathrm{a}}$ & $71.97 \pm 0.18^{\mathrm{a}}$ & $69.48 \pm 0.14^{\mathrm{c}}$ & $72.61 \pm 0.30^{\mathrm{a}}$ & $70.72 \pm 0.55^{\mathrm{b}}$ \\
Crude Protein & $15.92 \pm 0.33^{\mathrm{b}}$ & $15.22 \pm 0.03^{\mathrm{c}}$ & $17.17 \pm 0.19^{\mathrm{a}}$ & $15.27 \pm 0.12^{\mathrm{c}}$ & $17.37 \pm 0.16^{\mathrm{a}}$ \\
Lipids Total & $9.78 \pm 2.0^{\mathrm{b}}$ & $10.22 \pm 0.25^{\mathrm{b}}$ & $10.88 \pm 0.15^{\mathrm{a}}$ & $9.89 \pm 0.09^{\mathrm{b}}$ & $9.99 \pm 0.11^{\mathrm{b}}$ \\
Ash & $1.20 \pm 0.4^{\mathrm{a}}$ & $1.07 \pm 0.01^{\mathrm{c}}$ & $1.08 \pm 0.04^{\mathrm{bc}}$ & $1.15 \pm 0.04^{\mathrm{abc}}$ & $1.17 \pm 0.04^{\mathrm{ab}}$ \\
\hline
\end{tabular}

Means followed by different letters in the same row are significantly different $(\mathrm{P}<0.05)$ according to the Tukey test; means \pm standard deviation $(\mathrm{n}=6)$.

Table 5. Initial and final weight, weight gain, and specific growth rate of the fish fed experimental diets for 49 days.

\begin{tabular}{ccccc}
\hline \multirow{2}{*}{ Parameter } & \multicolumn{4}{c}{ Diets } \\
\cline { 2 - 5 } & A & B & C & D \\
\hline Initial weight (g) & $275.40 \pm 21.75$ & $335.68 \pm 46.95$ & $647.60 \pm 68.51$ & $349.62 \pm 77.36$ \\
Final weight (g) & $655.82 \pm 54.88$ & $676.22 \pm 130.51$ & $324.26 \pm 29.09^{\mathrm{a}}$ & $669.33 \pm 203.47$ \\
Weight gain (g) & $380.43 \pm 66.41^{\mathrm{a}}$ & $340.54 \pm 44.73^{\mathrm{a}}$ & $319.72 \pm 44.23^{\mathrm{a}}$ & $1.45 \pm 0.51^{\mathrm{a}}$ \\
SGR (\% day $\left.{ }^{-1}\right)$ & $1.77 \pm 0.27^{\mathrm{a}}$ & $1.44 \pm 0.32^{\mathrm{a}}$ & $1.32 \pm 0.37^{\mathrm{a}}$ & \\
\hline
\end{tabular}

Means followed by different letters in the same row are significantly different $(\mathrm{P}<0.05)$ according to the Tukey test; means \pm standard deviation $(\mathrm{n}=6)$; SGR $=$ specific growth rate. 
Table 6. Fatty acid profile ( $\mathrm{mg} \mathrm{g}^{-1}$ of total lipids) in fillets of pacu fed experimental diets after 49 days.

\begin{tabular}{|c|c|c|c|c|c|}
\hline \multirow{2}{*}{ Fatty Acids } & \multirow{2}{*}{ Initial } & \multicolumn{4}{|c|}{ Diets } \\
\hline & & $\mathrm{A}$ & $\mathrm{B}$ & $\mathrm{C}$ & $\mathrm{D}$ \\
\hline $14: 0$ & $27.48 \pm 0.39^{b}$ & $27.04 \pm 0.84^{b}$ & $29.60 \pm 0.20^{\mathrm{a}}$ & $25.57 \pm 0.26^{c}$ & $25.84 \pm 0.20^{c}$ \\
\hline $14: 1 n-7$ & $2.98 \pm 0.04^{\mathrm{a}}$ & $2.38 \pm 0.09^{c d}$ & $2.74 \pm 0.03^{\mathrm{b}}$ & $2.34 \pm 0.02^{\mathrm{d}}$ & $2.45 \pm 0.02^{c}$ \\
\hline 15:0 & $1.67 \pm 0.02^{\mathrm{e}}$ & $2.03 \pm 0.03^{\mathrm{b}}$ & $2.28 \pm 0.02^{\mathrm{a}}$ & $1.88 \pm 0.01^{\mathrm{c}}$ & $1.76 \pm 0.03^{\mathrm{d}}$ \\
\hline $15: 1 n-9$ & $1.49 \pm 0.03^{b c}$ & $1.42 \pm 0.02^{\mathrm{c}}$ & $1.67 \pm 0.02^{\mathrm{a}}$ & $1.67 \pm 0.04^{\mathrm{a}}$ & $1.56 \pm 0.05^{\mathrm{b}}$ \\
\hline $16: 0$ & $233.92 \pm 1.09^{\mathrm{b}}$ & $241.37 \pm 0.59^{\mathrm{a}}$ & $243.01 \pm 2.32^{\mathrm{a}}$ & $220.91 \pm 0.36^{c}$ & $219.00 \pm 0.64^{c}$ \\
\hline $16: 1 n-9$ & $3.53 \pm 0.06^{c}$ & $3.56 \pm 0.03^{c}$ & $3.74 \pm 0.04^{\mathrm{b}}$ & $4.06 \pm 0.02^{\mathrm{a}}$ & $3.66 \pm 0.02^{\mathrm{b}}$ \\
\hline $16: 1 n-7$ & $66.84 \pm 0.64^{\mathrm{a}}$ & $49.16 \pm 0.20^{\mathrm{d}}$ & $54.43 \pm 0.65^{\mathrm{b}}$ & $50.20 \pm 0.07^{c}$ & $49.41 \pm 0.23^{c d}$ \\
\hline $16: 1 n-5$ & $1.20 \pm 0.01^{\mathrm{c}}$ & $1.74 \pm 0.01^{\mathrm{a}}$ & $1.75 \pm 0.01^{\mathrm{a}}$ & $1.75 \pm 0.01^{\mathrm{a}}$ & $1.63 \pm 0.03^{\mathrm{b}}$ \\
\hline 17:0 & $2.45 \pm 0.01^{\mathrm{d}}$ & $3.40 \pm 0.02^{\mathrm{b}}$ & $3.53 \pm 0.02^{\mathrm{a}}$ & $3.54 \pm 0.01^{\mathrm{a}}$ & $3.12 \pm 0.03^{c}$ \\
\hline $17: 1 n-9$ & $2.30 \pm 0.05^{c}$ & $2.46 \pm 0.05^{\mathrm{b}}$ & $2.84 \pm 0.03^{\mathrm{a}}$ & $2.53 \pm 0.05^{\mathrm{b}}$ & $2.26 \pm 0.06^{c}$ \\
\hline 18:0 & $77.80 \pm 0.48^{\mathrm{d}}$ & $87.02 \pm 1.45^{\mathrm{bc}}$ & $85.53 \pm 0.62^{c}$ & $92.73 \pm 0.28^{\mathrm{a}}$ & $88.56 \pm 0.44^{\mathrm{b}}$ \\
\hline $18: 1(11 t)$ & $1.83 \pm 0.04^{\mathrm{e}}$ & $4.14 \pm 0.32^{\mathrm{c}}$ & $2.75 \pm 0.05^{\mathrm{d}}$ & $15.70 \pm 0.20^{\mathrm{a}}$ & $10.58 \pm 0.35^{\mathrm{b}}$ \\
\hline $18: \ln -9$ & $358.26 \pm 2.17^{\mathrm{a}}$ & $348.91 \pm 1.99^{b}$ & $333.68 \pm 1.12^{\mathrm{d}}$ & $339.51 \pm 0.68^{c}$ & $350.20 \pm 0.19^{b}$ \\
\hline $18: 1 n-7$ & $19.58 \pm 0.12^{\mathrm{a}}$ & $16.63 \pm 0.20^{\mathrm{d}}$ & $16.53 \pm 0.05^{\mathrm{d}}$ & $18.88 \pm 0.08^{b}$ & $17.63 \pm 0.03^{c}$ \\
\hline $18: 2 n-6$ & $106.50 \pm 0.23^{\mathrm{e}}$ & $122.23 \pm 0.34^{\mathrm{a}}$ & $108.89 \pm 0.44^{\mathrm{c}}$ & $107.64 \pm 0.21^{\mathrm{d}}$ & $121.39 \pm 0.21^{\mathrm{b}}$ \\
\hline $18: 3 n-6$ & $1.56 \pm 0.03^{\mathrm{e}}$ & $2.16 \pm 0.01^{\mathrm{b}}$ & $1.61 \pm 0.02^{\mathrm{d}}$ & $1.90 \pm 0.02^{c}$ & $2.23 \pm 0.01^{\mathrm{a}}$ \\
\hline $18: 3 n-3$ & $6.99 \pm 0.02^{\mathrm{e}}$ & $8.40 \pm 0.05^{c}$ & $29.16 \pm 0.17^{\mathrm{a}}$ & $7.47 \pm 0.02^{\mathrm{d}}$ & $14.35 \pm 0.01^{\mathrm{b}}$ \\
\hline 20:1n-9 & $1.17 \pm 0.02^{\mathrm{d}}$ & $1.23 \pm 0.03^{c}$ & $1.14 \pm 0.03^{\mathrm{d}}$ & $1.52 \pm 0.02^{\mathrm{a}}$ & $1.32 \pm 0.02^{\mathrm{b}}$ \\
\hline $18: 2(9 c, 11 t)$ & nd & nd & nd & $12.52 \pm 0.03^{\mathrm{a}}$ & $3.86 \pm 0.04^{\mathrm{b}}$ \\
\hline $18: 2(10 t, 12 c)$ & nd & nd & nd & $7.66 \pm 0.06^{\mathrm{a}}$ & $1.85 \pm 0.06^{\mathrm{b}}$ \\
\hline $20: 2 n-6$ & $4.62 \pm 0.02^{c}$ & $4.52 \pm 0.13^{c}$ & $4.31 \pm 0.03^{\mathrm{d}}$ & $5.58 \pm 0.03^{\mathrm{a}}$ & $5.12 \pm 0.04^{\mathrm{b}}$ \\
\hline $20: 3 n-6$ & $1.07 \pm 0.02^{c}$ & $1.05 \pm 0.04^{c}$ & $1.03 \pm 0.03^{c}$ & $1.12 \pm 0.01^{\mathrm{b}}$ & $1.18 \pm 0.02^{\mathrm{a}}$ \\
\hline 22:0 & $2.65 \pm 0.01^{\mathrm{a}}$ & $2.50 \pm 0.04^{\mathrm{bc}}$ & $2.48 \pm 0.02^{\mathrm{c}}$ & $2.55 \pm 0.02^{\mathrm{b}}$ & $2.65 \pm 0.02^{\mathrm{a}}$ \\
\hline $22: 1 n-9$ & $1.56 \pm 0.03^{\mathrm{d}}$ & $1.78 \pm 0.05^{c}$ & $1.49 \pm 0.01^{\mathrm{e}}$ & $2.24 \pm 0.01^{\mathrm{a}}$ & $2.16 \pm 0.04^{\mathrm{b}}$ \\
\hline $20: 3 n-3$ & $4.17 \pm 0.09^{\mathrm{d}}$ & $4.54 \pm 0.09^{\mathrm{b}}$ & $3.90 \pm 0.06^{\mathrm{e}}$ & $4.36 \pm 0.03^{c}$ & $4.75 \pm 0.04^{\mathrm{a}}$ \\
\hline $20: 4 n-6$ & $7.30 \pm 0.15^{\mathrm{abc}}$ & $6.95 \pm 0.13^{b c}$ & $5.97 \pm 1.49^{c}$ & $8.46 \pm 0.06^{a}$ & $8.29 \pm 0.22^{\mathrm{ab}}$ \\
\hline $20: 5 n-3$ & $1.06 \pm 0.02^{\mathrm{c}}$ & $0.75 \pm 0.08^{\mathrm{d}}$ & $1.52 \pm 0.01^{\mathrm{a}}$ & $1.01 \pm 0.02^{c}$ & $1.22 \pm 0.03^{\mathrm{b}}$ \\
\hline $22: 4 n-6$ & $1.89 \pm 0.06^{\mathrm{d}}$ & $2.06 \pm 0.06^{\mathrm{c}}$ & $2.03 \pm 0.04^{c}$ & $2.72 \pm 0.02^{\mathrm{a}}$ & $2.46 \pm 0.04^{\mathrm{b}}$ \\
\hline $22: 5 n-3$ & $0.75 \pm 0.02^{\mathrm{cd}}$ & $0.68 \pm 0.07^{\mathrm{d}}$ & $1.31 \pm 0.04^{\mathrm{a}}$ & $0.82 \pm 0.02^{c}$ & $1.05 \pm 0.02^{\mathrm{b}}$ \\
\hline $22: 6 n-3$ & $5.47 \pm 0.13^{\mathrm{a}}$ & $2.97 \pm 0.12^{\mathrm{d}}$ & $5.06 \pm 0.14^{\mathrm{b}}$ & $4.16 \pm 0.05^{c}$ & $4.29 \pm 0.16^{c}$ \\
\hline SFA & $345.97 \pm 1.53^{c}$ & $363.37 \pm 0.92^{\mathrm{a}}$ & $366.44 \pm 2.09^{a}$ & $347.18 \pm 0.79^{c}$ & $340.94 \pm 0.91^{\mathrm{d}}$ \\
\hline MUFA & $460.73 \pm 2.25^{\mathrm{a}}$ & $433.42 \pm 1.55^{\mathrm{c}}$ & $422.75 \pm 1.52^{\mathrm{d}}$ & $440.40 \pm 0.65^{\mathrm{b}}$ & $442.87 \pm 0.33^{b}$ \\
\hline PUFA & $141.38 \pm 0.40^{\mathrm{d}}$ & $156.31 \pm 0.76^{c}$ & $164.80 \pm 1.49^{\mathrm{b}}$ & $165.43 \pm 0.28^{b}$ & $172.05 \pm 0.60^{\mathrm{a}}$ \\
\hline$n-6$ & $122.94 \pm 0.30^{c}$ & $138.98 \pm 0.56^{\mathrm{b}}$ & $123.85 \pm 1.56^{\mathrm{c}}$ & $147.62 \pm 0.25^{\mathrm{a}}$ & $146.39 \pm 0.51^{\mathrm{a}}$ \\
\hline $\mathrm{n}-3$ & $18.44 \pm 0.22^{c}$ & $17.33 \pm 0.24^{\mathrm{e}}$ & $40.96 \pm 0.13^{\mathrm{a}}$ & $17.81 \pm 0.07^{\mathrm{d}}$ & $25.66 \pm 0.18^{\mathrm{b}}$ \\
\hline PUFA/SFA & $0.41 \pm 0.00^{\mathrm{e}}$ & $0.43 \pm 0.00^{\mathrm{d}}$ & $0.45 \pm 0.01^{\mathrm{c}}$ & $0.48 \pm 0.00^{\mathrm{b}}$ & $0.50 \pm 0.00^{\mathrm{a}}$ \\
\hline$n-6 / n-3$ & $6.67 \pm 0.08^{c}$ & $8.02 \pm 0.09^{b}$ & $3.02 \pm 0.04^{\mathrm{e}}$ & $8.29 \pm 0.03^{\mathrm{a}}$ & $5.71 \pm 0.04^{\mathrm{d}}$ \\
\hline
\end{tabular}

Means followed by different letters in the same row are significantly different $(\mathrm{P}<0.05)$ according to the Tukey test; Means \pm standard deviation $(\mathrm{n}=6)$; $\mathrm{SFA}=$ total saturated fatty acids; MUFA = total monounsaturated fatty acids; PUFA = total polyunsaturated fatty acids; $\mathrm{n}-6=$ total $\mathrm{n}-6$ fatty acids; $\mathrm{n}-3=$ total $\mathrm{n}-3$ fatty acids; nd $=$ not detected $\left(\right.$ detection limit $\left.=0.015 \mathrm{mg} \mathrm{g}^{-1}\right)$.

Diets $\mathrm{A}$ and $\mathrm{B}$ resulted in an increase $(\mathrm{P}<0.05)$ in the total SFA in the fillets in relation to the beginning of the experiment. Regarding the amount of PUFA, there was an increase $(\mathrm{P}<0.05)$ in all diets, but it was highest in the fish fillets fed diet D. Justi et al. (2003) found no difference in the SFA and PUFA concentrations in fillets of Nile Tilapia (Oreochromis niloticus) fed a diet supplemented with linseed.

The PUFA/SFA and n- $6 / \mathrm{n}-3$ ratios can be used as parameters to indicate whether a given food is healthy. According to The Health (1994) recommendations, the values for PUFA/SFA should be above 0.45 Martin et al. (2006) and Simopoulos (2008), state that the ratio may vary between $2-4 / 1$ according to the disease in question. In the present study, the PUFA/SFA and n-6/n-3 ratios of the fillets of fish fed diets $B, C$ and $D$ reached the recommended values (Table 4).

An increase $(\mathrm{P}<0.05)$ in the concentration of LNA was observed in the fish fillets fed $\operatorname{diet} \mathrm{A}$ in relation to time zero. The fish fed the diet enriched with linseed oil (diet B) had an increase of $317 \%$ in the concentration of LNA, rising from 6.99 to $29.16 \mathrm{mg} \mathrm{g}^{-1} \mathrm{TL}$ after 49 days. In the fish fillets fed diet $\mathrm{D}$, in which $0.5 \%$ LNA and $0.5 \%$ CLA were added, the concentration of LNA by the end of the experiment was $14.35 \mathrm{mg} \mathrm{g}^{-1} \mathrm{TL}$, which corresponds to an increase of $105 \%$ in relation to time zero. These results prove that the composition of the diets used in the present study directly influenced the composition of the fish fillets. 
(a)

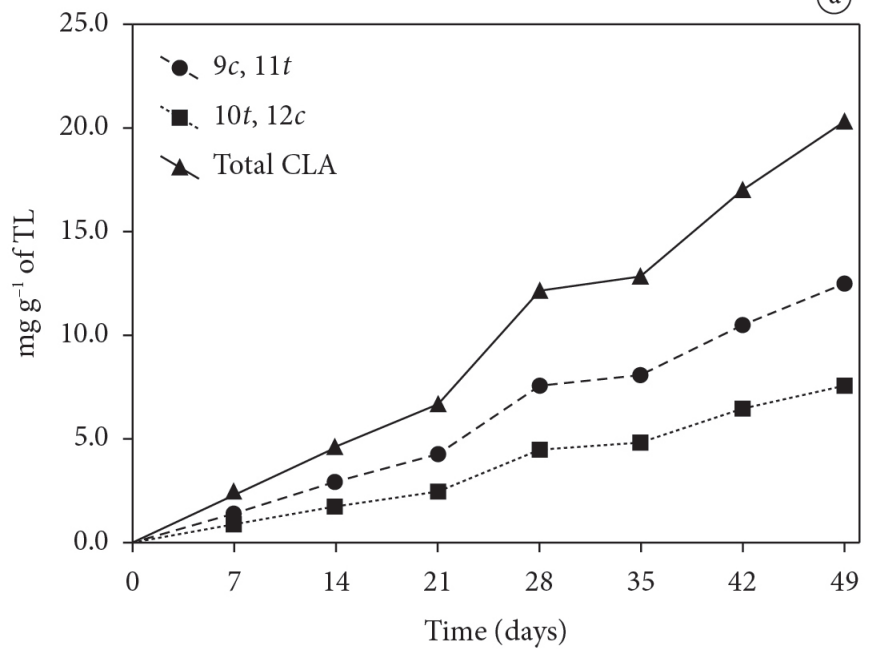

(b)

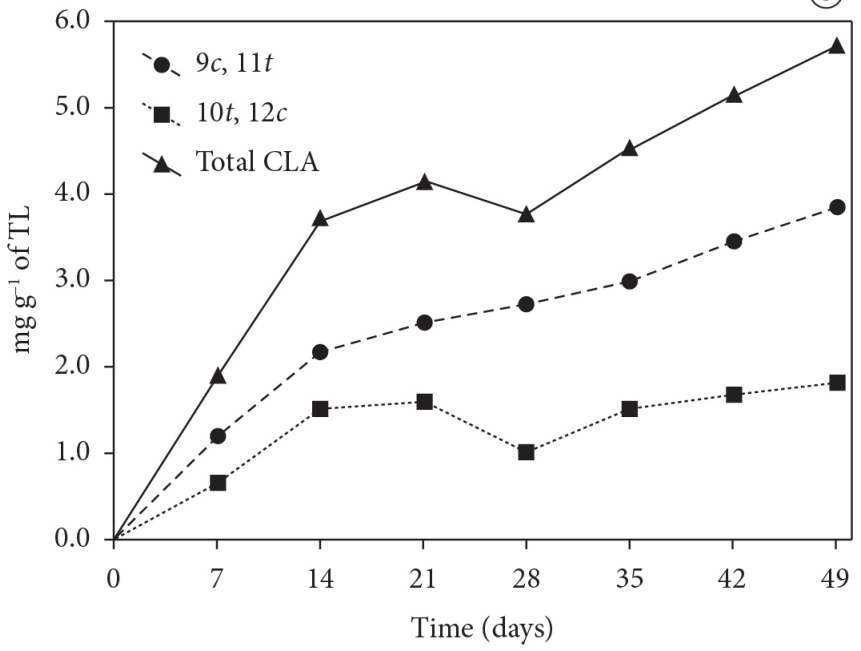

Figure 1. Incorporation of isomers $9 c, 11 t ; 10 t, 12 c$ and total CLA in the fillets of Piaractus mesopotamicus fed diets C (a) and D $(b)$ for 49 days.

These results can be compared to those obtained by Justi et al. (2003) in a study conducted with Nile Tilapia, in which the authors used diets enriched with $3.75 \%$ linseed oil and also verified an increase of $290 \%$ in the concentration of LNA in the fillets.

The concentration of EPA in the fish fillets fed diet A was lower compared with that at the beginning of the experiment due to the presence of PUFA n-6 in the diet. With regard to the fish fed diet $C$, no significant variation was observed in the concentration of EPA after 49 days. As for the fish fed diets $B$ and $\mathrm{D}$, there was an increase $(\mathrm{P}<0.05)$ in the concentration of EPA in the fillets with variations from $1.06 \mathrm{mg} \mathrm{g}^{-1} \mathrm{TL}$ (time zero) to 1.52 and $1.22 \mathrm{mg} \mathrm{g}^{-1} \mathrm{TL}$, respectively. This increase is mainly due to the incorporation of LNA and subsequent conversion to EPA by the process of elongation and desaturation, which proves the capacity of the pacu to perform this process. This is a desirable outcome since EPA is especially related to the protection of the cardiovascular health (Haglund et al., 1998), given that the eicosanoids derived from this acid have anti-inflammatory, antithrombotic, anti-arrhythmic, and vasodilatory properties.

The fatty acids of the n-3 family, especially EPA and DHA, are found in high concentrations in marine fish. Visentainer et al. (2000) determined the concentration of these fatty acids in some species of marine fish of the Brazilian coast. The observed values ranged between $94.8-186.8 \mathrm{mg} \mathrm{g}^{-1}$ for EPA and 137.7-165.0 $\mathrm{mg} \mathrm{g}^{-1}$ for DHA for the tuna, bonito, and sardine species.

The DHA concentrations in the fish fillets found at the end of the experiment were lower $(\mathrm{P}<0.05)$ in all diets in relation to the value determined initially (Table 6), different from the results of Zanqui et al. (2013) and Santos et al. (2007a), who did not observe reduction in the DHA levels in fish fillets fed diets containing CLA.

The liver is considered the primary site for biosynthesis of DHA, which becomes available for uptake and subsequent secretion into circulating blood stream. Twibell et al. (2000) suggested that the DHA is "captured" by the fish liver, and thus its amount in the muscles is reduced, which would explain such decrease. Moreover, DHA is one of the major components of brain and retinal cell membranes, playing an important role in the formation and operation of these organs (Lauritzen, 2001).

Figure 1 shows the profile of the incorporation of isomers $9 c, 11 t$ and $10 t, 12 c$, and the total CLA (sum of the two isomers) in the fish fillets fed diets $\mathrm{C}$ and $\mathrm{D}$ and collected every 7 days.

The supplementation of CLA in diets C and D resulted in a significant increase $(\mathrm{P}<0.05)$ in the concentrations of isomers $9 c, 11 t$ and $10 t, 12 c$, and total CLA in the fillets. The concentrations of total CLA at the end of the study were $20.18 \mathrm{mg} \mathrm{g}^{-1}(\operatorname{diet} \mathrm{C})$ and $5.71 \mathrm{mg} \mathrm{g}^{-1}(\operatorname{diet} \mathrm{D})$; for the isomers $9 c, 11 t$ and $10 t, 12 c$, they were 12.52 and $7.66 \mathrm{mg} \mathrm{g}^{-1}$ (diet C) and 3.86 and $1.85 \mathrm{mg} \mathrm{g}^{-1}$ (diet D), respectively. The difference in the incorporation of the isomers is due to the fact that $9 c, 11 t$ is better incorporated into the lipid fractions (Yu et al., 1998), whereas $10 t, 12 c$ is related to energy metabolism (Pariza et al., 2001). The concentrations of CLA found in the muscle of Striped bass was $73.0 \mathrm{mg} \mathrm{g}^{-1}$ (Twibell et al., 2000); $19.0 \mathrm{mg} \mathrm{g}^{-1}$ in codfish fingerlings (Kennedy et al., 2007); and $35.8 \mathrm{mg} \mathrm{g}^{-1}$ in the muscle of pacu (Santos et al., 2009). These results indicate that the ability of fish to accumulate CLA varies according to the species; a consequence of differences in energy, metabolism, or diet composition (Santos et al., 2007b).

\section{Conclusion}

Fish adapt to cultivation in net cages, and the diets utilized were well accepted and did not affect their growth. The LNA present in the diet resulted in the incorporation of this acid in the fillets of P. mesopotamicus, increasing the EPA content and reducing the n-6/n-3 ratio. However, the DHA contents did not change. P. mesopotamicus also demonstrated CLA-incorporation ability. These results contributed to an improvement in the nutritional quality of the meat of this fish. 


\section{Acknowledgements}

The authors thank the Group of Studies of Management in Fish Farming (Grupo de Estudos de Manejo na Aquicultura - GEMAq, Unioeste), Itaipu Binacional and the National Council for Scientific and Technological Development (Conselho Nacional de Desenvolvimento Científico e Tecnológico - $\mathrm{CNPq}$ ) for the financial support.

\section{References}

Analytical Methods Committee (1987). Recommendations for the definition, estimation and use of the detection limit. Analyst, 112(2), 199-204. http://dx.doi.org/10.1039/an9871200199

Bligh, E. G., \& Dyer, W. J. (1959). A rapid method of total lipid extraction and purification. Biochemistry and Cell Biology, 37(8), 911-7.

Castagnolli, N., \& Cyrino, J. E. P. (1986). Piscicultura nos Trópicos. São Paulo: Manole.

Chin, S. F., Liu, W., Storkson, J. M., Ha, Y. L., \& Pariza, M. W. (1992). Dietary sources of conjugated dienoic isomers of linoleic acid, a newly recognized class of anticarcinogens. Journal of Food Composition and Analysis, 5(3), 185-97. http://dx.doi. org/10.1016/0889-1575(92)90037-K

Chouinard, P. Y., Corneau, L., Saebø, A., \& Bauman, D. E. (1999). Milk yield and composition during abomasal infusion of conjugated linoleic acids in dairy cows. Journal of Dairy Science, 82(12), 273745. http://dx.doi.org/10.3168/jds.S0022-0302(99)75530-X

Cook, M. E., \& Pariza, M. (1998). The Role of Conjugated Linoleic Acid (CLA) in Health. International Dairy Journal, 8(5-6), 459-62. http://dx.doi.org/10.1016/S0958-6946(98)00069-7

Cunnif, P. A. (1998). Official methods of Analysis of AOAC international (16th ed.). Arlington: AOAC.

Fountoulaki, E., Vasilaki, A., Hurtado, R., Grigorakis, K., Karacostas, I., Nengas, I., Rigos, G., Kotzamanis, Y., Venou, B., \& Alexis, M. N. (2009). Fish oil substitution by vegetable oils in commercial diets for gilthead sea bream (Sparus aurata L.); effects on growth performance, flesh quality and fillet fatty acid profile. Aquaculture, 289(3-4), 31726. http://dx.doi.org/10.1016/j.aquaculture.2009.01.023

Gaullier, J. M., Halse, J., Hoye, K., Kristiansen, K., Fagertun, H., Vik, H., \& Gudmundsen, O. (2004). Conjugated linoleic acid supplementation for $1 \mathrm{y}$ reduces body fat mass in healthy overweight humans. American Journal of Clinical Nutrition, 79(6), 1118-25. PMid:15159244.

Ha, Y. L., Grimm, N. K., \& Pariza, M. W. (1987). Anticarcinogens from fried ground beef: heat-altered derivatives of linoleic acid. Carcinogenesis, 8(12), 1881-7. PMid:3119246. http://dx.doi. org/10.1093/carcin/8.12.1881

Haglund, O., Wallin, R., Wretling, S., Hultberg, B., \& Saldeen, T. (1998). Effects of fish oil alone and combined with long chain (n-6) fatty acids on some coronary risk factors in male subjects. Journal of Nutritional Biochemistry, 9(11), 629-35. http://dx.doi.org/10.1016/ S0955-2863(98)00065-5

Hartman, L., \& Lago, R. C. (1973). Rapid preparation of fatty acid methyl esters from lipids. Laboratory practice, 22(6), 475-6 passim. PMid:4727126.

Health, D. (1994). Report on Health and Social Subjects $n^{\circ} 46$. Nutritional Aspects of Cardiovascular Disease. London: HMSO.

Henderson, R. J. (1996). Fatty acid metabolism in freshwater fish with particular reference to polyunsaturated fatty acids. Archiv für Tierernaehrung, 49(1), 5-22. http://dx.doi. org/10.1080/17450399609381859

Ip, C., Briggs, S. P., Haegele, A. D., Thompson, H. J., Storkson, J., \& Scimeca, J. A. (1996). The efficacy of conjugated linoleic acid in mammary cancer prevention is independent of the level or type of fat in the diet. Carcinogenesis, 17(5), 1045-50. PMid:8640911. http:// dx.doi.org/10.1093/carcin/17.5.1045

Izquierdo, M. S., Montero, D., Robaina, L., Caballero, M. J., Rosenlund, G., \& Ginés, R. (2005). Alterations in fillet fatty acid profile and flesh quality in gilthead seabream (Sparus aurata) fed vegetable oils for a long term period. Recovery of fatty acid profiles by fish oil feeding. Aquaculture, 250(1-2), 431-44. http://dx.doi.org/10.1016/j. aquaculture.2004.12.001

Joseph, J. D., \& Ackman, R. G. (1992). Capillary column gaschromatographic method for analysis of encapsulated fish oils and fish ethyl-esters - colaborative study. Journal of Aoac International, 75(3), 488-506.

Justi, K. C., Hayashi, C., Visentainer, J. V., De Souza, N. E., \& Matsushita, M. (2003). The influence of feed supply time on the fatty acid profile of Nile tilapia (Oreochromis niloticus) fed on a diet enriched with n-3 fatty acids. Food Chemistry, 80(4), 489-93. http://dx.doi.org/10.1016/ S0308-8146(02)00317-5

Kennedy, S. R., Bickerdike, R., Berge, R. K., Porter, A. R., \& Tocher, D. R. (2007). Influence of dietary conjugated linoleic acid (CLA) and tetradecylthioacetic acid (TTA) on growth, lipid composition and key enzymes of fatty acid oxidation in liver and muscle of Atlantic cod (Gadus morhua L.). Aquaculture, 264(1-4), 372-82. http:// dx.doi.org/10.1016/j.aquaculture.2007.01.013

Kimura, Y., Takaku, T., Nakajima, S., \& Okuda, H. (2001). Effects of carp and tuna oils on 5-fluorouracil-induced antitumor activity and side effects in sarcoma 180-bearing mice. Lipids, 36(4), 353-9. PMid:11383685. http://dx.doi.org/10.1007/s11745-001-0727-3

Kritchevsky, D., Tepper, S. A., Wright, S., Czarnecki, S. K., Wilson, T. A., \& Nicolosi, R. J. (2004). Conjugated linoleic acid isomer effects in atherosclerosis: Growth and regression of lesions. Lipids, 39(7), 6116. PMid:15588017. http://dx.doi.org/10.1007/s11745-004-1273-8

Lauritzen, L. (2001). The essentiality of long chain n-3 fatty acids in relation to development and function of the brain and retina. Progress in Lipid Research, 40(1-2), 1-94. http://dx.doi.org/10.1016/ S0163-7827(00)00017-5

Leaver, M. J., Tocher, D. R., Obach, A., Jensen, L., Henderson, R. J., Porter, A. R., \& Krey, G. (2006). Effect of dietary conjugated linoleic acid (CLA) on lipid composition, metabolism and gene expression in Atlantic salmon (Salmo salar) tissues. Comparative biochemistry and physiology Part A, Molecular \& integrative physiology, 145(2), 25867. PMid:16904357. http://dx.doi.org/10.1016/j.cbpa.2006.06.034

Martin, C. A., Almeida, V. V., Ruiz, M. R., Visentainer, J. E. L., Matshushita, M., Souza, N. E., \& Visentainer, J. V. (2006). Ácidos graxos poliinsaturados ômega-3 e ômega-6: importância e ocorrência em alimentos. Revista de Nutrição, 19. http://dx.doi. org/10.1590/S1415-52732006000600011

Mayser, P., Mrowietz, U., Arenberger, P., Bartak, P., Buchvald, J., Christophers, E., Jablonska, S., Salmhofer, W., Schill, W. B., Krämer, H. J., Schlotzer, E., Mayer, K., Seeger, W., \& Grimminger, F. (1998). Omega-3 Fatty acid-based lipid infusion in patients with chronic plaque psoriasis: Results of a double-blind, randomized, placebocontrolled, multicenter trial. Journal of the American Academy of Dermatology, 38(4), 539-47. http://dx.doi.org/10.1016/S01909622(98)70114-8

Moreira, A. B., Visentainer, J. V., De Souza, N. E., \& Matsushita, M. (2001). Fatty acids profile and cholesterol contents of three Brazilian 
Brycon freshwater fishes. Journal of Food Composition and Analysis, 14(6), 565-74. http://dx.doi.org/10.1006/jfca.2001.1025

Navarro, R. D., Silva Pereira Navarro, F. K., Ribeiro Filho, O. P., Ferreira, W. M., Pereira, M. M., \& Seixas Filho, J. T. (2012). Quality of polyunsaturated fatty acids in Nile tilapias (Oreochromis niloticus) fed with vitamin E supplementation. Food Chemistry, 134(1), 215-8. http://dx.doi.org/10.1016/j.foodchem.2012.02.097

Pariza, M. W., Park, Y., \& Cook, M. E. (2001). The biologically active isomers of conjugated linoleic acid. Progress in Lipid Research, 40(4), 283-98. http://dx.doi.org/10.1016/S0163-7827(01)00008-X

Sanderson, P., Finnegan, Y. E., Williams, C. M., Calder, P. C., Burdge, G. C., Wootton, S. A., Griffin, B. A., Joe Millward, D., Pegge, N. C., \& Bemelmans, W. J. (2002). UK Food Standards Agency alphalinolenic acid workshop report. British Journal of Nutrition, 88(5), 573-9. PMid:12425738. http://dx.doi.org/10.1079/BJN2002691

Santos, L. D., Furuya, W. M., Castro Silva, T. S., Michelato, M., \& Matsushita, M. (2009). Ácido linoléico conjugado em dietas para pacu: tempo de deposição, desempenho e perfil de ácidos graxos. Revista Brasileira de Zootecnia, 38(6), 980-8. http://dx.doi. org/10.1590/S1516-35982009000600002

Santos, L. D., Furuya, W. M., Matsushita, M., Silva, L. C. R., Silva, T. S. C., Botaro, D., \& Sales, P. P. (2007a). Deposição de ácido linoléico conjugado (CLA) em tilápias-do-nilo. Revista Brasileira de Zootecnia, 36(5), 1225-30. http://dx.doi.org/10.1590/S151635982007000600002

Santos, L. D., Furuya, W. M., Matsushita, M., Silva, L. C. R., Silva, T. S. C., \& Botaro, D. (2007b). Ácido linoléico conjugado (CLA) em dietas para tilápia-do-nilo: desempenho produtivo, composição química e perfil de ácidos graxos. Revista Brasileira de Zootecnia, 36(5), 1481-8. http://dx.doi.org/10.1590/S1516-35982007000700004
Simopoulos, A. P. (2002). Omega-3 fatty acids in wild plants, nuts and seeds. Asia Pacific Journal of Clinical Nutrition, 11, S163-S73. http:// dx.doi.org/10.1046/j.1440-6047.11.s.6.5.x

Simopoulos, A. P. (2008). The Importance of the Omega-6/Omega-3 Fatty Acid Ratio in Cardiovascular Disease and Other Chronic Diseases. Experimental Biology and Medicine, 233(6), 674-88. PMid:18408140. http://dx.doi.org/10.3181/0711-MR-311

Twibell, R. G., Watkins, B. A., Rogers, L., \& Brown, P. B. (2000). Effects of dietary conjugated linoleic acids on hepatic and muscle lipids in hybrid striped bass. Lipids, 35(2), 155-61. PMid:10757546. http:// dx.doi.org/10.1007/BF02664765

Visentainer, J. V., Carvalho, P. O., Ikegaki, M., \& Park, Y. K. (2000). Concentração de ácido eicosapentaenóico (EPA) e ácido docosahexaenóico (DHA) em peixes marinhos da costa brasileira. Ciência e Tecnologia de Alimentos, 20(1), 90-3. http://dx.doi. org/10.1590/S0101-20612000000100017

Visentainer, J. V., De Souza, N. E., Makoto, M., Hayashi, C., \& Franco, M. R. B. (2005). Influence of diets enriched with flaxseed oil on the alpha-linolenic, eicosapentaenoic and docosahexaenoic fatty acid in Nile tilapia (Oreochromis niloticus). Food Chemistry, 90(4), 557-60. http://dx.doi.org/10.1016/j.foodchem.2004.05.016

Visentainer, J. V., \& Franco, M. R. B. (2006). Ácidos graxos em óleos e gorduras: identificação e quantificação. Varela.

Yu, L., Donkin, S. S., \& Watkins, B. A. (1998). CLA reduced arachidonic acid formation in primary cultures of rat hepatocytes. FASEB Journal, 12(4), A535.

Zanqui, A. B., Maruyama, S. A., Barilli, D. J., Ribeiro, S. A. O., Gomes, S. T. M., Visentainer, J. V., Souza, N. E., Boscolo, W. R., \& Matsushita, M. (2013). Incorporation of conjugated linoleic and alpha linolenic fatty acids into Pimedolus maculatus fillets. Food Science and Technology (Campinas), 33(3), 532-40. http://dx.doi.org/10.1590/ S0101-20612013005000066 